\title{
A gyógyszeresen kezelt jóindulatú prosztatamegnagyobbodásban szenvedő betegek életminősége Magyarországon - Keresztmetszeti felmérés hat urológiai centrumban
}

\author{
Kovács Ágnes dr. 1,2,3
}

'Budapesti Corvinus Egyetem, Gazdálkodástani Doktori Iskola, Budapest (igazgató: Michalkó Gábor dr.) ²Budapesti Corvinus Egyetem, Egészségügyi Közgazdaságtan Tanszék, Budapest (tanszékvezető: Gulácsi lászló dr.)

3Boehringer-Ingelheim RCV, Magyarország (igazgató: Francesco Banchi dr.)

Levelezési cím:

dragneskovacs70@gmail.com

\section{ÖSSZEFOGLALÁS}

Célkitüzés: Vizsgálatunk célja az urológiai ellátásban megjelenő, gyógyszeres kezelésben részesülő BPH-betegek életminőségének felmérése volt.

Betegek és módszer: A keresztmetszeti kérdőíves felmérésre 2014-ben került sor 6 urológiai osztályon. Összesen 246 (18 éves vagy idősebb), gyógyszeresen kezelt jóindulatú prosztatamegnagyobbodásban szenvedő férfi vett részt, életkoruk átlag 70,6 (SD 8,1) év volt. Az átlagos betegség fennállási idő 6,5 év (SD 6,2) volt. A Nemzetközi Prosztata Tünetértékelő Skála összpontszám átlaga 12,8 (SD 6,3) volt a mintában.

Eredmények: Az összpontszám alapján 52 (23\%), 136 (61\%), és 35 (16\%) beteg került az enyhe, mérsékelt és súlyos tünetekkel rendelkező jóindulatú prosztatamegnagyobbodás alcsoportokba. A betegek EQ-5D indexszel és EQ VAS-sal mért egészségi állapota rendre 0,85 (SD 0,19) és 68,4 (SD 15,5) volt, a súlyossági alcsoportok közötti különbség mindkettő esetében szignifikáns $(p<0,05)$.

Megbeszélés: A vizsgálatban résztvevő betegek EQ-5D átlaga hasonló volt, mint a nemre és korra illesztett általános populációé, kivéve a 45-49, illetve 55-59 éveseket, ahol szignifikánsan rosszabb, illetve jobb értéket mértünk.

\section{KULCSSZAVAK}

BPH, ÉLETMINŐSÉG, I-PSS, EQ-5D, MAGYARORSZÁG
The life quality of patients with benign prostate hyperlasia treated medically in Hungary: a cross-sectional survey in six urological departments

\section{SUMMARY}

Objective: The aim of the study was to assess the quality of life of BPH patients receiving medication in urological care.

Patients and methods: A cross sectional survey was conducted in 2014 in 6 urological departments in Hungary. A total number of 246 medically treated males aged 18 years or over participated who had been diagnosed with benign prostatic hyperplasia. Patients' mean age was 70,6 (SD 8, 1) years and the average disease duration was 6,5 (SD 6,2) years.

Results: The average of International prostate Symptom Score was 12.8 (SD 6.3). Based on the total score 52 (23\%), $136(61 \%)$, and 35 (16\%) patients belonged to the mild, moderate and severe benign prostatic hyperplasia subgroups. Health status of the patients measured with EQ-5D index and EQ VAS scores were 0.85 (SD 0.19) and 68.4 (SD 15.5), respectively and the difference between severity subgroups was significant for both.

Conclusion: Patients' average EQ-5D index score was similar to the gender and age-matched population norm, except in age-groups 45-49 and 55-59 where patients' scores were significantly lower and higher, respectively.

\section{KEYWORDS}

BPH, Quality of Life, I-PSS, EQ-5D, Hungary 
A z alsó húgyúti tüneteket okozó jóindulatú prosztatamegnagyobbodás (benignus prosztata-hiperplázia, továbbiakban BPH) az egyik leggyakrabban előforduló urológiai rendellenesség, amely a 40 év felettiek 10-46\%-át érinti (1) Az idősödés, a BPH kialakulásának fő kockázati tényezője, jelentős társadalmi problémát jelent, különösen a társadalombiztosítás, nyugdíjrendszer, valamint az egészségügyi szolgáltatások finanszírozása és teljesítése terén (2). Várhatóan 2050-re 58 millió 65 éven felüli személy fog az Európai Unió területén élni $(3,4)$. Az EU jelenlegi 27 tagállamában az egészségügyi kiadások az előrejelzések szerint 2010 és 2060 között a GDP 7,1\%-ról 8,4\%-ra emelkedik, ami tisztán az öregedő populáció egészségügyi kiadásokra gyakorolt hatásának tulajdonítható (5).

Az életkorral összefüggő betegségek, mint például a BPH, a 2-es típusú cukorbetegség, a demencia, csontritkulás, húgyhólyagrák és prosztatarák mára az egészségügyi finanszírozás fő költségtényezőivé váltak (6-14). A várható élettartam növekedése, a fejlett országokban megfigyelhető demográfiai öregedés és a BPH magas előfordulási gyakorisága miatt egyre több férfi vesz igénybe egészségügyi szolgáltatásokat a $\mathrm{BPH}$ tünetei miatt $(15,16)$.

A BPH kezelése jellemzően a betegség súlyosságától függ, fő lehetőségei az éber várakozás („watchful waiting” - rendszeres kontroll specifikus terápia alkalmazása nélkül), a gyógyszeres kezelés, illetve különböző mútéti eljárások (17-19). A költségek azonban jelentős változékonyságot mutathatnak (20, 21) tehát a fenti kezelési modalitások gazdasági kiértékelése nagyon hasznos az egészségügyi döntéshozatal költséghatékonyságának elősegítésében, valamint a rendszer meglévő hiányosságainak könnyebb kiiktatásában. A jól megalapozott egészségügyi technológiai értékelő szervezetekkel rendelkező országokban a gazdasági kiértékelés az egészségügyi döntéshozatal kulcsfontosságú részét képezi (22-25).

A költséghatékonysági elemzés során az életminőségben bekövetkezett változásokat vetik össze a költségekben bekövetkező változásokkal, lehetőség szerint az adott országra jellemző, helyi adatok felhasználásával (26-28). Magyarországon kevés ismeret áll rendelkezésre a BPH-val összefüggő életminőség változásokról.

Vizsgálatunk célja az urológiai ellátásban megjelenő, gyógyszeres kezelésben részesülő BPH-betegek életminőségének felmérése volt. Kutatásunkkal betekintést szeretnénk nyerni a betegek szemszögéből a BPH-betegség okozta terhekre, életminőség változásokra, amelyek jobb megismerése segítik a klinikai döntéshozatalt, értékes szempontokat adhatnak az orvos-beteg kommunikáció javításához. Másrészt életminőség alapadatokkal kívánunk szolgálni hazai egészség-gazdaságtani felmérésekhez.

\section{Betegek és módszer}

Beavatkozással nem járó multicentrikus keresztmetszeti kérdőíves vizsgálatot végeztünk 2014. június és október között. Hat urológiai centrum vett részt a vizsgálatban, egy egyetemi klinika, 4 kórház urológiai osztálya és annak ambulanciája és egy vidéki szakrendelő-intézet járóbeteg-szakrendelése.

Olyan gyógyszeresen kezelt BPH-diagnózissal rendelkező betegeket vontunk be a vizsgálatba, akik esetén prosztatamútét nem szerepelt az anamnézisükben. Az adatgyújtésre, azaz a kérdőívek kitöltésére akkor került sor, amikor a betegek járóbeteg-szakellátás keretében felkeresték urológus szakorvosukat. A kutatás lefolytatásához az etikai engedélyt az Egészségügyi Tudományos Tanács adta ki, referenciaszám: 24197-2/2014/EKU, és minden beteg aláírta a kutatásban való részvételét megerősítő beleegyező nyilatkozatot.

A kérdőív első része, amelyet a betegek töltöttek ki, tartalmazta a demográfiai és a munkavégzéssel kapcsolatos kérdéseket, a beteg állapotára vonatkozó klinikai jellemzőket, az önbevalláson alapuló betegségsúlyosság, és az általános egészségi állapottal kapcsolatos életminőség-kérdőívet (lásd lentebb), valamint az egészségügyi szolgáltatások a kérdőív kitöltését megelőző 12 hónapra vonatkozó igénybevételére vonatkozó kérdéseket.

Az urológus szakorvosok töltötték ki a kérdőív második részét. Ennek a résznek a kitöltése részben a beteg dokumentáció alapján történt, amelyben megtalálhatók a betegségfennállás hosszára, a diagnosztikus tesztekre és az alkalmazott terápiára vonatkozó adatok. A kitöltéskor a kérdőíves felmérést megelőző 12 hónapra vonatkozó adatok kerültek összegyújtésre. A szakorvosok által kitöltött második rész további adatai a betegek aktuális állapotára, vizsgálati eredményeire és terápiájára vonatkoztak.

Az alkalmazott mércék a következők voltak:

1. az általános életminőséget vizsgáló EQ-5D-3L kérdőív;

2. a betegségspecifikus, a betegség súlyosságának megítélésére alkalmas I-PSS. (Nemzetközi Prosztata Tünetértékelő Skála; International Prostate Symptom Score).

Az EQ-5D-3L és I-PSS kérdőívek validáltak, magyar nyelven is elérhetők, ezek kerültek kutatásunkban felhasználásra.

Az I-PSS 7 elemet tartalmaz a vizeletürítésre és tartásra vonatkozóan 1 hónapos időtartammal, a válaszok 0-5 közötti értéket kapnak (29). Az I-PSS pontszáma ezen hét kérdés alapján számolható, 0 és 35 közötti értéket vehet fel, ahol a magasabb érték súlyosabb állapotnak felel meg. Az I-PSS pontszám alapján a betegek enyhe (I-PSS 0-7), mérsékelt (I-PSS 8-19) és súlyos (I-PSS 20-35) alcsoportokba lettek bekategorizálva. Az I-PSS kiegészül egy életminőséggel kapcsolatos kérdéssel, amelynek értéktartománya 0-6.

A betegek általános, egészséggel összefüggő életminőségét az EQ-5D-3L (a továbbiakban: EQ-5D) kérdőívvel mértük fel (30). Az EQ-5D egy leíró részből és egy 20 cm-es függőleges egészség-hőmérőből (vizuális analóg skála, EQ VAS) áll. A leíró rész az egészség 5 dimenzióját vizsgálja (ezek a következők: mozgékonyság, önellátás, szokásos tevékenységek, fájdalom/rossz közérzet és szorongás/lehangoltság), mindegyik dimenzióban 3 féle válaszlehetőség közül kell megjelölnie az egyénnek a rá aznap leginkább jellemző választ, ahol az 1 - nincs probléma, 2 - némi probléma és a 3 - súlyos probléma $(31,4)$. Az EQ VAS két végpontja (0-100) az elképzelhető legrosszabb, illetve legjobb egészségi állapotot jelenti, amelyen a betegnek a ská- 
lán az aznapi állapotukat kell megjelölniük. A kérdőív leíró részéból ún. hasznosság érték számolható (EQ-5D index), amely az adott egészségi állapot preferáltságát tükrözi, társadalmi szemszögből. Magyarországon, hazai egészségi állapot hasznosság eredmények hiányában, az Egyesült Királyságban használatos értékeket szokták alkalmazni (31). Értéktartománya 0,594-1, a magasabb érték jobb állapotra utal.

A Boldogság VAS-on (tartománya 0-10) a válaszadó az adott aktuális pillanatban érzékelt boldogság értéket tünteti fel, a skála két végpontja: 0 - nagyon boldogtalan, 10 - nagyon boldog.

Statisztikai analízis során az adatokat SPSS 22.0 programcsomag használatával rögzítettük és analizáltuk. Leíró statisztikai elemzést végeztünk a változók vizsgálatára. A csoportok öszszehasonlítására az ANOVA-módszertant alkalmaztuk a kvantitatív adatokra és chi-négyzet tesztet a kvalitatív adatokra. Minden teszt esetében az eredményeket akkor tekintettük szignifikánsnak amennyiben $\mathrm{p}<0,05$ volt.

\section{Eredmények}

A betegek főbb demográfiai és klinikai jellemzői az 1. és 2. táblázatban kerültek összefoglalásra. Összesen 246 beteg vett részt a kutatásban, az átlagos életkor 70,6 év (SD 8,1 év), az átlagos betegség fennállási idő pedig 6,5 év (SD 6,2 év) volt. A testtömegindex (BMI) alapján 182 beteg (74\%) volt túlsúlyos vagy elhízott (BMl>25).

1. TÁBLÁZAT: A BETEGEK DEMOGRÁFIAI JELLEMZÖI ( $\mathrm{N}=246)$

\begin{tabular}{lc}
\hline Demográfiai jellemzők & $\begin{array}{c}\text { n (\%) vagy } \\
\text { átlag } \pm \text { szórás }\end{array}$ \\
\hline Életkor (év) & $70,59 \pm 8,13$ \\
BMI $\left(\mathrm{kg} / \mathrm{m}^{2}\right)$ & $27,68 \pm 3,88$ \\
Legmagasabb iskolai végzettség $(\mathrm{n}=245)$
\end{tabular}

2. TÁBLÁZAT: A BETEGEK KLINIKAI JELLEMZŐI

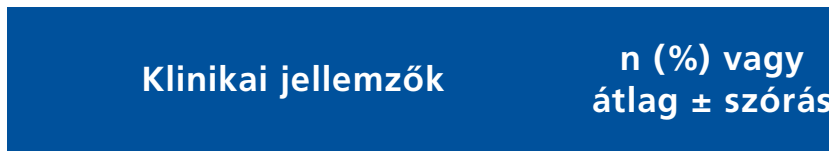

Betegség fennállási idő (év) ( $\mathrm{n}=243$ ) 6,5 $\quad$ 6,2

Tünetek a felmérés időpontjában

Sürgető vizelési inger $(n=238)$

$119(50 \%)$

Vizelettartás zavara $(n=240)$

$21(9 \%)$

Gyakori vizeletürítés ( $n=239$ )

$108(45 \%)$

$\begin{array}{ll}\text { Nappali vizeletürítések száma }(\mathrm{db})^{*} & 7,5 \pm 2,6 \\ \text { Éjszakai vizeletürítések száma }(\mathrm{db})^{*} & 3,3 \pm 1,7\end{array}$

Állandó katéter ( $n=244)$

$19(8 \%)$

Fennálló mútéti indikáció ( $n=236)$

$42(18 \%)$

Tünetek az elmúlt 12 hónap során

Akut vizeletretenció $(n=242)$

$45(18 \%)$

Sürgető vizelési inger $(n=243)$

$163(67 \%)$

Vizelettartás zavara $(n=243)$

$38(16 \%)$

Gyakori vizeletürítés ( $n=241$ )

$119(49 \%)$

$\begin{array}{ll}\text { Nappali vizeletürítések száma }(\mathrm{db}) * & 8,1 \pm 1,9 \\ \text { Éjszakai vizeletürítések száma }(\mathrm{db}) \text { * } & 3,1 \pm 1,4\end{array}$

Terápia az elmúlt 12 hónap során**

Alfa-blokkoló (AB)

$158(64,2 \%)$

5-alfa-reduktáz-inhibitor (5-ARI)

$15(6,1 \%)$

Kombinált terápia $(A B+5-A R I)$

$25(10,2 \%)$

Antimuszkarinok

$9(3,7 \%)$

Fitoterápia

$108(43,9 \%)$

Mútét indikált

$42(18 \%)$

Éber várakozás (Watchful waiting)

$28(11 \%)$

Egyéb

$1(0,4 \%)$

Betegségsúlyosság
I-PSS (0-35) $(n=223)$
$12,80 \pm 6,34$
Enyhe (I-PSS 0-7)
$52(23 \%)$
Mérsékelten súlyos (8-19)
$136(61 \%)$
Súlyos (20-35)
$35(16 \%)$

Egészséggel összefüggő életminőség

EQ-5D $(-0,594-1)(n=237)^{* * *} \quad 0,85 \pm 0,19$

EQ VAS $(0-100)(n=233)^{* * *} \quad 68,37 \pm 15,54$

I-PSS 8. életminőség kérdés (0-6) $(n=227)$

$2,46 \pm 1,62$

Boldogság vizuális analóg skála (VAS)

$(0-10) * * *(n=235)$

$6,26 \pm 2,19$

* Azok közül, akiknél gyakori vizeletürítés fordult elő, ** Egy beteg többféle terápiában is részesülhet, ${ }^{* * *} \mathrm{~A}$ magasabb pontszám jobb egészségi állapotra utal 
A betegek 64,2\%-a alfa-blokkoló, 6,1\%-a 5-alfa-reduktáz-gátló és 10,2\%-a pedig kombinált kezelésben részesült (5-alfa-reduktázgátló + alfa-blokkoló kombinációja). Antimuszkarin kezelést a betegek 3,7\%-a kapott. A kitöltés időpontjában a kezelés ellenére a betegek közel felének volt valamilyen vizelési panasza.

Vizelési panaszok miatt a betegek 10\%-a feküdt kórházban a kérdőív kitöltését megelőző 12 hónapban (e betegek 90\%-a 1 alkalommal, 10\%-a 2 alkalommal), 18\%-uk járt panaszai miatt háziorvosnál és 76\%-uk urológus szakorvosnál. Összesen 42 beteg (17\%) várt prosztatamútétre a kérdőív kitöltésekor, átlagéletkor: 70,93 (SD 6,82), a mútétre nem váró 194 beteg átlagéletkora 70,39 (SD 8,42) volt (10 beteg esetén nem állt rendelkezésre életkorra vonatkozó adat).

Az I-PSS pontszám átlaga 12,8 (SD=6,3) volt a mintában. Az I-PSS pontszám alapján 52 (23\%), 136 (61\%), és 35 (16\%) tartozott az enyhe, mérsékelt és súlyos BPH-csoportokba.

A betegek EQ-5D-index és EQ VAS-értékének átlaga rendre $0,85(S D=0,19)$ és $68,4(S D=15,5)$ volt. Száztizenegy beteg (45\%) EQ-5D-index értéke volt 1-gyel egyenlő. Összesen 7\%, 19\%, 28\%, 30\%, illetve 31\% jelentett mérsékelt vagy súlyos problémát az önellátás, szokásos tevékenységek, szorongás/depresszió, fájdalom/rossz közérzet és mozgékonyság területén (1. ábra).

A BPH-betegek EQ-5D-vel mért általános életminőségét a tünetek és betegsúlyosság alapján képzett alcsoportokban a 3 . táblázat tartalmazza. Az EQ-5D átlagértékeket az I-PSS-CSOportokban néztük, statisztikailag szignifikáns eltérést találtunk. Vizsgáltuk a korrelációt az egyes alcsoportok között, a folytonos változók közötti korrelációk pedig a 4. táblázatban kerültek feltüntetésre.

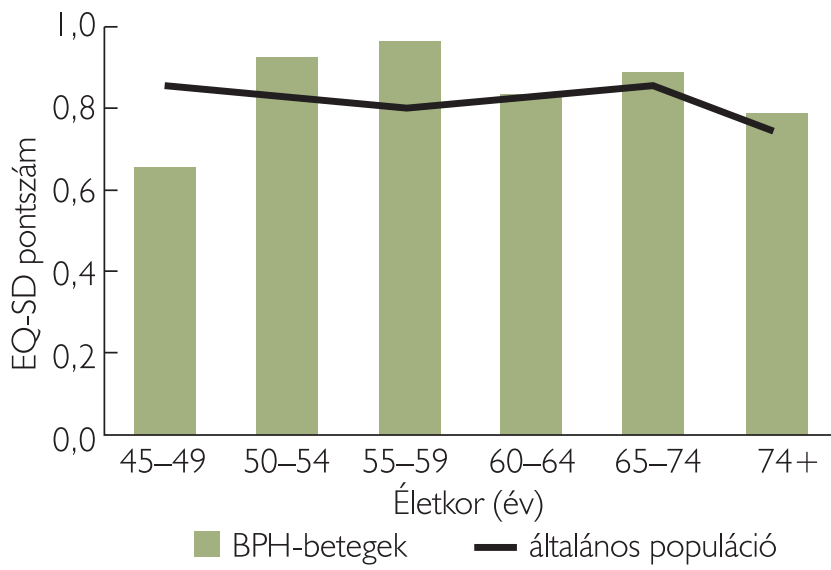

\section{1. ÁBRA: BPH-BETEGEK ÉS AZ ÁLTALÁNOS POPULÁCIÓ} (65 ÉVES ÉS IDŐSEBB FÉRFIAK) ÖSSZEHASONLÍTÁSA AZ EQ-5D KÉRdőív 5 DIMENZIÓJÁBAN (FORRÁS: BAJI, ET AL. 2015) (4)

A BPH-betegek és a nemben és korban illesztett általános populáció EQ-5D-index értékeinek összehasonlítása a 2. ábrán került feltüntetésre.

A 65-69 és 70-74 éves korcsoportok összevontan kerültek bemutatásra a hazai populációs vizsgálatban, az összehasonlíthatóság miatt ezt követtük BPH-betegek esetén is.

A BPH-betegek és a nemben és korban illesztett általános populáció között csak a 45-49 és az 55-59 éves korosztályban volt szignifikáns az eltérés ( $p<0,05)$.

\section{TÁBLÁZAT: BPH/LUTS-BETEGEK EQ-5D-VEL MÉRT ÁLTALÁNOS ÉLETMINŐSÉGE TÜNETEK ÉS BETEGSÚLYOSSÁG ALAP-} JÁN KÉPZETT ALCSOPORTOKBAN

\begin{tabular}{|c|c|c|c|c|c|c|c|}
\hline Változók & & $\mathbf{n}$ & $\begin{array}{l}\text { Q-5D index } \\
\pm \text { szórás } \\
(-0,594-1)\end{array}$ & $\mathbf{p}$ & $\mathbf{n}$ & $\begin{array}{l}\text { EQ VAS } \\
\pm \text { szórás } \\
(0-100)\end{array}$ & $\mathbf{p}$ \\
\hline \multicolumn{8}{|l|}{ Jelenlegi tünetek } \\
\hline \multirow{2}{*}{ Sürgető vizelési inger } & Igen & 115 & $0,85 \pm 0,20$ & \multirow{2}{*}{0,638} & 112 & $67,22 \pm 15,75$ & \multirow{2}{*}{0,151} \\
\hline & Nem & 116 & $0,87 \pm 0,15$ & & 113 & $70,61 \pm 14,76$ & \\
\hline \multirow{2}{*}{ Vizelettartás zavara } & Igen & 20 & $0,78 \pm 0,27$ & \multirow{2}{*}{0,221} & 21 & $61,95 \pm 16,86$ & \multirow{2}{*}{$0,041^{*}$} \\
\hline & Nem & 214 & $0,86 \pm 0,18$ & & 208 & $69,45 \pm 15.0$ & \\
\hline \multirow{2}{*}{ Gyakori vizeletürítés } & Igen & 103 & $0,82 \pm 0,22$ & \multirow{2}{*}{0,024 * } & 102 & $66,98 \pm 15,81$ & \multirow{2}{*}{0,166} \\
\hline & Nem & 128 & $0,88 \pm 0,15$ & & 124 & $70,13 \pm 14,80$ & \\
\hline \multirow{2}{*}{ Állandó katéter } & Igen & 17 & $0,77 \pm 0,23$ & \multirow{2}{*}{0,100} & 17 & $56,24 \pm 17,33$ & \multirow{2}{*}{$0,002^{*}$} \\
\hline & Nem & 220 & $0,86 \pm 0,18$ & & 216 & $69,33 \pm 15,01$ & \\
\hline \multirow{2}{*}{ Fennálló mútéti indikáció } & Igen & 40 & $0,79 \pm 0,22$ & \multirow{2}{*}{$0,029 *$} & 40 & $63,15 \pm 16,47$ & \multirow{2}{*}{$0,016^{*}$} \\
\hline & Nem & 197 & $0,86 \pm 0,18$ & & 193 & $69,46 \pm$ & \\
\hline \multicolumn{8}{|l|}{ Betegségsúlyosság } \\
\hline Enyhe (I-PSS 0-7) & 50 & $0,90 \pm 0,12$ & & 51 & $72,86 \pm 14,65$ & & \\
\hline Mérsékelten súlyos (I-PSS 8-19) & 134 & $0,87 \pm 0,14$ & $0,002^{*}$ & 133 & $69,16 \pm 14,63$ & $<0,001^{*}$ & \\
\hline Súlyos (I-PSS 20-35) & 34 & $0,71 \pm 0,31$ & & 34 & $59,04 \pm 16,02$ & & \\
\hline
\end{tabular}

* Mann-Whitney U-teszt vagy Kruskal-Wallis-teszt $p<0,05$ szignifikáns, § A magasabb pontszám jobb egészségi állapotra utal 


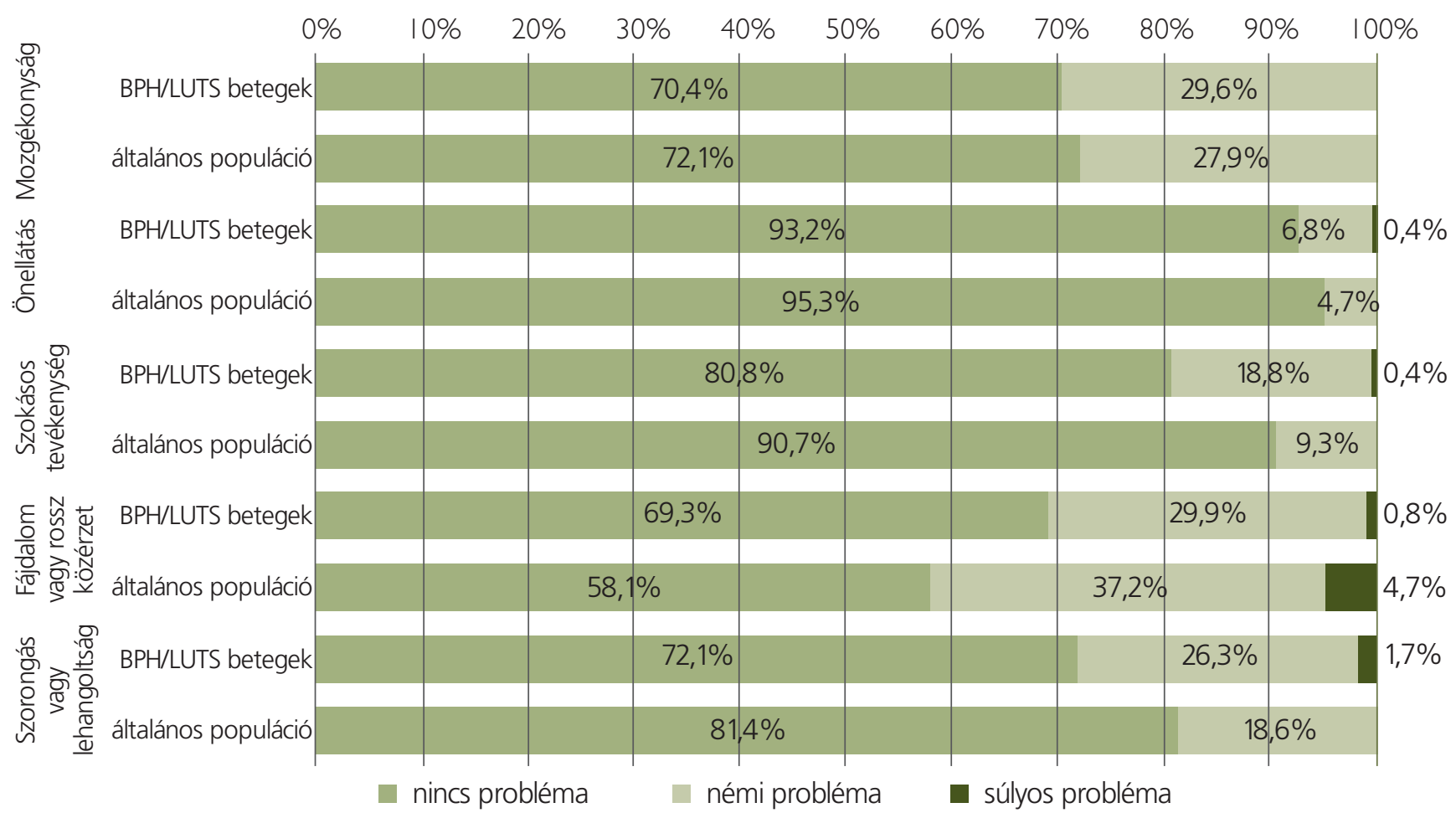

\section{2. ÁBRA: BPH-BETEGEK ÉS A NEMBEN ÉS KORBAN ILLESZTETt ÁltALÁNOS POPULÁCIÓ EQ-5D INDEX ÉRTÉKEINEK ÖSSZE-} HASONLÍTÁSA (FORRÁSA: BAJI ET AL. 2015) (4)

\section{Megbeszélés}

A vizsgálatunkban BPH-betegek klinikai jellemzőit, egészséggel összefüggő életminőségét vizsgáltuk. Eredményeink közül fontosnak tartjuk kiemelni, hogy a betegek közel felének a gyógyszeres kezelés ellenére vizelési panaszai voltak, amely legtöbbször a gyakori vizeletürítés és a parancsoló vizelési in- ger volt. A mintánkban szereplő legtöbb beteg általános egészségi állapotát jónak itélte meg az EQ-5D alapján, a betegek megközelítőleg fele (45\%) nem jelölt problémát kérdőív öt dimenziója egyikében sem. A BPH-betegek EQ-5D-index átlaga a 45-49 éves korosztályban alacsonyabb, a 60-64 évesek esetén azonos, míg az 50-54, 55-59 és a 65-74 éves korosztályban magasabb volt, mint nem és kor szerint illesztett általános populációé (32) (2. ábra).

4. TÁBLÁZAT: FOLYTONOS VÁLTOZÓK KÖZÖTTI KORRELÁCIÓ

\begin{tabular}{|c|c|c|c|c|c|c|c|c|}
\hline Változók & EQ VAS & I-PSS & $\begin{array}{l}\text { I-PSS } 8 . \\
\text { életminő- } \\
\text { ség kérdés }\end{array}$ & $\begin{array}{l}\text { Boldog- } \\
\text { ság }\end{array}$ & Életkor & BMI & $\begin{array}{c}\text { Nappali } \\
\text { vizelet- } \\
\text { ürítések } \\
\text { száma }\end{array}$ & $\begin{array}{c}\text { Éjszakai } \\
\text { vizelet- } \\
\text { ürítések } \\
\text { száma }\end{array}$ \\
\hline EQ-5D§ $(-0,594-1)$ & $0,55^{* * *}$ & $-0,16^{*}$ & $-0,20$ ** & $0,35^{* \star *}$ & $-0,20^{* *}$ & 0,69 & $-0,17$ & $-0,24^{*}$ \\
\hline EQ VAS§ (0-100) & - & $-0,20$ ** & $-0,21^{* *}$ & $0,58^{* * *}$ & $-0,22^{* *}$ & $-0,08$ & $-0,05$ & $-0,38^{* * *}$ \\
\hline I-PSS (0-35) & - & - & $0,70 * * *$ & $-0,43^{* * *}$ & $0,14^{*}$ & $-0,01$ & $0,21^{*}$ & $0,34 * *$ \\
\hline $\begin{array}{l}\text { I-PSS 8. életminőség kérdés } \\
(0-6)\end{array}$ & - & - & - & $-0,35^{\star * *}$ & 0,11 & $-0,03$ & 0,09 & $0,37^{* * *}$ \\
\hline Boldogság ${ }^{\S}(0-10)$ & - & - & - & - & $-0,20$ ** & 0,08 & $-0,10$ & $-0,26^{* *}$ \\
\hline Életkor (év) & - & - & - & - & - & $-0,20 * *$ & $-0,04$ & $-0,01$ \\
\hline BMI $\left(\mathrm{kg} / \mathrm{m}^{2}\right)$ & - & - & - & - & - & - & 0,09 & 0,16 \\
\hline $\begin{array}{l}\text { Nappali vizeletürítések } \\
\text { száma (db) }\end{array}$ & - & - & & - & - & - & - & $-0,22^{\star}$ \\
\hline
\end{tabular}

*Spearman-korreláció $p<0,05,{ }^{* *} p<0,01,{ }^{* * *} p<0,001,{ }^{\S} \mathrm{A}$ magasabb pontszám jobb egészségi állapotra utal 
Az EQ-5D-index átlaga a teljes mintában 0,85 (SD=0,19) volt, amely más országokból származó tanulmányok megállapításaihoz hasonló volt. Ezek az értékek az egyes országokban a következők: Spanyolország: 0,90, SD=0,14, átlagéletkor: 63 év (33); Franciaország: 0,84, SD=0,19, átlagéletkor: 72 év (34); Korea: 0,85, SD=0,19, átlagéletkor: 76 év (35); és az Egyesült Királyság: 0,71-0,87 a súlyosságtól függően, átlagéletkor: 73 év (36). A nemzetközi összehasonlítást nehezíti, hogy a BPH életminőségtanulmányok részben randomizált kontrollált klinikai vizsgálatok voltak $(37,38)$, részben gyógyszervizsgálattal kapcsolatos keresztmetszeti felmérések (33). A BPH életminőséggel kapcsolatos kutatások csak kisebb részében alkalmazták az EQ-5D mércét és ahol alkalmazták, nem közöltek populációs átlaggal történt öszszehasonlítást. Eltérők voltak a beválogatási kritériumok is, emiatt a nemzetközi összehasonlítás nehézségekbe ütközik.

Az I-PSS összpontszám növekedésével szignifikánsan csökkent az EQ-5D-index értéke, azaz a betegség súlyosságával roszszabbodott az általános életminőség (3. táblázat). Az EQ-5D és az I-PSS pontszám között szignifikáns, de gyenge korrelációt találtunk, és ugyancsak az I-PSS életminőség kérdéssel is. Eredményeink alapján elmondható, hogy a gyógyszeres kezelés alatt álló BPH-betegek egészséggel összefüggő életminősége átlagosan nem rosszabb, mint az általános lakosságé. Az eredmény értékelésében figyelembe kell venni, hogy vizsgálatunkban az EQ-5D általános életminőség kérdőívet használtuk, amely a kisebb eltérések kimutatására kevéssé alkalmas. Az 50-54, 55-59, 65-74 és a 75+ korcsoportban a BPH-betegek esetén jobb egészséggel összefüggő életminőség értékeket kaptunk, mint a korra és nemre illesztett általános lakosságban, ezek közül csak az 55-59 évesek esetén volt a különbség szignifikáns. A 60-64 évesek esetén nem találtunk különbséget. A 45-49 éves korcsoportban a BPH-betegek életminősége szignifikánsan rosszabb volt, mint az átlag populációé (2. ábra). Abban, hogy a 45-49 éves BPH-betegek szignifikánsan rosszabbnak ítélték életminőségüket szerepe lehet az egészségi állapottal kapcsolatos várakozásoknak is, ebben az életkorban valószínúleg a BPH-tünetek jelenlétének elfogadottsága alacsony. Az, hogy a BPH-betegek általános életminőség értékei többségében hasonlók illetve jobbak, mint az általános lakosságé azzal is magyarázható, hogy a be- tegek hat vezető urológiai centrumban kezelt betegek voltak. Feltehető, hogy ezekbe a centrumokba eleve a jobb társadalmi-gazdasági hátterű betegek kerültek (az átlag 71 éves betegcsoportban 30\% volt a felsőfokú végzettségúek aránya), akiknek az életminősége is magasabb, mint a társadalmi átlag. Illetve az okok között az is megemlíthető, hogy a bármi ok miatt prosztatamútéten átesett betegeket nem válogattuk be a mintába, elképzelhető, hogy az ő esetükben más eredményre jutottunk volna.

Az életminőség vizsgálata révén számos olyan összefüggés tárható fel, amelyekkel javítani lehet az ilyen jellegú betegségek kezelésének hatékonyságát. Jelen tanulmány a magyarországi gyógyszeresen kezelt BPH-betegek életminőség-felmérésével ezt a célt szolgálja.

A felmerésünk korlátai közé tartozik, hogy csak nagy betegszámmal rendelkező ellátóhelyek vettek benne részt; elképzelhető, hogy az urológiai centrumok véletlen beválogatása esetén kissé más képet kaptunk volna. További limitáció, hogy a gyógyszeres kezelés ellenére meglévő panaszok hátterében levő okok nem derülnek ki; ismeretlen, hogy a kezelés hatékonysága elégtelen vagy a betegek nem megfelelő gyógyszerszedése az ok. Ennek kiderítése jelen tanulmánynak nem volt célja.

\section{Köszönetnyilvánítás}

Köszönetemet szeretném kifejezni a közös kutatásért a következő kollegáknak: Dr. Nyirády Péter, dr. Majoros Attila Semmelweis Egyetem, Urológiai Klinika; Dr. Tenke Péter, dr. Németh, Jahn Ferenc Dél-pesti Kórház, Urológiai Osztály; Dr. Nagy Gábor János Szt. Borbála Kórház Tatabánya Urológiai Osztály; Dr. Nagy János Szentgotthárd Rendelőintézet, Urológia ambulancia; Dr. Buzogány István, Fővárosi Önkormányzat Péterfy Sándor Utcai Kórház, Integrált Urológia és Sebészeti Osztály; Dr. Böszörményi-Nagy Géza, Bajcsy-Zsilinszky Kórház és Rendelőintézet Urológiai Osztály; Rencz Fanni, Brodszky Valentin. Péntek Márta, Gulácsi László Egészségügyi Közgazdaságtan Tanszék, Budapesti Corvinus Egyetem. Dr. Kovács Ágnes a Budapesti Corvinus Egyetem PhD hallgatója és a Boehringer-Ingelheim alkalmazottja. Jelen tanulmány a Boehringer-Ingelheim cégtöl független tanulmány.

\section{Irodalom}

1. Speakman M, Kirby R, Doyle $S$, et al. Burden of male lower urinary tract symptoms (LUTS) suggestive of benign prostatic hyperplasia (BPH) - focus on the UK. BJU International 2014; 508-519.

2. Shrestha LB. Population aging in developing countries. Health Affairs (Millwood) 2000; 19(3): 204-12. https://doi.org/10.1377/ hlthaff.19.3.204

3. REGIONS 2020. An Assessment of Future Challenges, for EU Regions.

4. Baji P, Brodszky V, Rencz F. et al. Health status of the Hungarian population between 2000-2010. Orv Hetil 2015; 156(50): 2035-
2044. doi: 10.1556/650.2015.30288 https://doi.org/10.1556/650 2015.30288

5. The 2012 Ageing Report, Economic and budgetary projections for the 27 EU Member States (2010-2060). http://ec.europa.eu/ economy_finance/publications/european_economy/2012/pdf/ee2012-2_en.pdf letöltés dátuma 2017-07-30

6. Brodszky V, Balint $P_{1}$ Geher $P_{1}$ et al. Disease burden of psoriatic arthritis compared to rheumatoid arthritis, Hungarian experiment. Rheumatology International 2009; 30(2): 199-205. doi: 10.1007/ s00296-009-0936-1. https://doi.org/10.1007/s00296-009-0936-1 
7. Ersek K, Kovacs T, Wimo A, et al. Costs of dementia in Hungary. The Journal of Nutrition Health and Aging 2010; 14(8): 633-639. https://doi.org/10.1007/s 12603-010-0309-1

8. Hever NV, Pentek M, Ballo A. et al. Health Related Quality of Life in Patients with Bladder Cancer: A Cross-Sectional Survey and Validation Study of the Hungarian Version of the Bladder Cancer Index. Pathology and Oncology Research 2014; 21(3): 619-627. doi: 10.1007/s12253-014-9866-7 https://doi.org/10.1007/s12253-014-9866-7

9. Pentek M, Horvath C, Boncz I, et al. Epidemiology of osteoporosis related fractures in Hungary from the nationwide health insurance database. 1999-2003. Osteoporos International 2008; 19(2): 243-9. https://doi.org/10.1007/s00198-007-0453-6

10. Rencz F, Brodszky V, Péntek M, et al. Disease burden of psoriasis associated with psoriatic arthritis in Hungary.[Arthritis psoriaticával társuló középsúlyos és súlyos psoriasis betegségterhe Magyarországon]. Orvosi Hetilap 2014; 155(48): 1913-1921. https://doi.org/1 $0.1556 / \mathrm{OH} .2014 .30044$

11. Rencz F, Brodszky V, Varga $P$, et al. The economic burden of prostate cancer. A systematic literature overview of registry-based studies.[A prosztatarák gazdasági terhe nagy betegregiszterek alapján] Orvosi Hetilap 2014; 155(13): 509-20. doi:10.1556/ oh.2014.29837 https://doi.org/10.1556/OH.2014.29837

12. Rencz F, Hollo $P$, Karpati $S$, et al. Moderate to severe psoriasis patients' subjective future expectations regarding health-related quality of life and longevity. Journal of the European Academy of Dermatology and Venereology

13. Rencz F, Gulacsi L, Tamasi B, et al. Health related quality of life and its determinants in pemphigus: a systematic review and metaanalysis. British Journal of Dermatology 2015. https://doi.org/ 10.1111/bjd. 13848

14. Tamas G, Gulacsi L, Bereczki D, et al. Quality of life and costs in Parkinson's disease: a cross sectional study in Hungary. PLoS One 2014t; 9(9): e107704. doi:10.1371/journal.pone.0107704 https:// doi.org/10.1371/journal.pone. 0107704

15. Boncz I, Vajda R, Agoston I, et al. Changes in the health status of the population of Central and Eastern European countries between 1990 and 2010. The European Journal of Health Economics 2014): 15(Suppl 1): S137-141. doi:10.1007/s10198-014-0602$8 \mathrm{https}: / /$ doi.org/10.1007/s 10198-014-0602-8

16. Rencz F. Health economics analysis of benign prostatic hyperplasia [A jóindulatú prosztatamegnagyobbodás egészség-gazdaságtani elemzése]. Köz-Gazdaság 2012; 7(3): 135-151.

17. Romics I. (Conservative treatment of benign prostatic hyperplasia. Orv Hetil 2008 Oct 5; 149(40): 1875-80. doi: 10.1556/OH.2008.28462. https://doi.org/10.1556/OH 2008.28462

18. Riesz P. "A benignus prostata hyperplasia" Hippocrates 2006; 8(1): $11-13$.

19. Bajory Z. A BPH progressziója és a mútéti kezelés indikációi. Magyar Urológia 2012; 3: 111.

20. Taub DA, Wei JT. The economics of benign prostatic hyperplasia and lower urinary tract symptoms in the United States. Current urology reports 2006; 7(4): 272-281. https://doi.org/10.1007/s11934996-0006-0

21. Kovács Á. Cost of illness in benign prostatic hyperplasia: A review. Society and Economy 2015; 37(4): 531-542. DOI: 10.1556/204.2015. 37.4.7

22. Gulacsi L, Pentek M. HTA in Central and Eastern European countries; the 2001: a space odyssey and efficiency gain. European Journal of Health Economics 2014; 15(7): 675-680. https://doi.org/ 10.1007/s 10198-014-0608-2

23. Gulacsi L, Rencz F, Pentek M, et al. Transferability of results of cost utility analyses for biologicals in inflammatory conditions for
Central and Eastern European countries. European Journal of Health Economics 2014; 15(Suppl 1): 27-34. https://doi.org/ 10.1007/s 10198-014-0591-7

24. Gulacsi L, Rotar AM, Niewada M, et al. Health technology assessment in Poland, the Czech Republic, Hungary, Romania and Bulgaria. The European Journal of Health Economics 2014; 15(Suppl 1): 13-25.

25. Boncz I, Sebestyén A. Financial deficits in the health services of the UK and Hungary. Lancet 2006 Sep 9; 368(9539): 917-8. https:// doi.org/10.1016/S0140-6736(06)69369-0

26. Gulácsi L, Frans Rutten, Marc A. Koopmanschap. Költségszámítás, in Egészség-gazdaságtan. Budapest: Medicina Könyvkiadó RT; 2005. 8. fejezet p. 191-262.

27. Gulácsi L, Boncz I, Baji P, Péntek M. Költségszámítás in Egészséggazdaságtan és technológiaelemzés. Budapest: Medicina Könyvkiadó Nyrt; 2012. 5. fejezet p. 135-184.

28. Az Emberi Erőforrások Minisztériuma szakmai irányelve az egészségügyi technológia értékelés módszertanáról és ennek keretében költséghatékonysági elemzések készítéséről hatályos: 2017.02.20 http://www.hbcs.hu/uploads/jogszabaly/2481/fajlok/egeszsegugyi_te chnologia_ertekeles.pdf

29. Barry MJ, Fowler FJ Jr, O'Leary MP, et al. The American Urological Association symptom index for benign prostatic hyperplasia. The Measurement Committee of the American Urological Association. The Journal of Urology 1992; 148(5): 1549-1557; discussion 1564 https://doi.org/10.1016/50022-5347(17)36966-5

30. Gulácsi L. Egészség-gazdaságtani elemzés. In Gulácsi L, Egészséggazdaságtan és technológiaelemzés. Budapest: Medicina Könyvkiadó ZRT; 2012. 6. fejezet p. 191-233.

31. Dolan P. Modeling valuations for EuroQol health states. Medical Care 1997; 35(11): 1095-1108. https://doi.org/10.1097/00005650199711000-00002

32. Szende A, Nemeth R. [Health-related quality of life of the Hungarian population]. Orvosi hetilap 2003; 144(34): 1667-1674.

33. Castro-Diaz D, Diaz-Cuervo H, Perez M. [Benign prostatic hyperplasia and its treatment: impact on quality of life and sexual function]. Actas Urologicas Espanolas 2013; 37(4): 233-241. doi:10.1016/j.acuro.2012. $08.001 \mathrm{https} / / / \mathrm{doi}$. org/10.1016/j.acuro.2012.08.001

34. Fourcade RO, Lacoin F, Roupret M, et al. Outcomes and general health-related quality of life among patients medically treated in general daily practice for lower urinary tract symptoms due to benign prostatic hyperplasia. World Journal of Urology 2012; 30(3): 419-426. doi:10.1007/s00345-011-0756-2; https://doi.org/10.1007/ s00345-011-0756-2

35. Song HJ, Han MA, Kang HC, et al. Impact of lower urinary tract symptoms and depression on health-related quality of life in older adults. International neurourology journal 2012; 16(3): 132-138. doi:10.5213/inj.2012.16.3.132 https://doi.org/10.5213/inj.2012.16.3.132

36. Trueman P, Hood SC, Nayak US, et al. Prevalence of lower urinary tract symptoms and self-reported diagnosed 'benign prostatic hyperplasia', and their effect on quality of life in a communitybased survey of men in the UK. BJU international 1999; 83(4): 410415. https://doi.org/10.1046/j.1464-410x.1999.00966.x

37. Herdman M, Pavesi M, Devlin N, et al. Using Eq-5d-3-L and Oab-5d to assess changes in health-related quality of life (Hrqol) in men with lower urinary tract symptoms (Luts) associate $d$ with benign prostatic hyperplasia (Bph). Value in Health PUK29. 2014; 17: A295.

38. Hakimi Z, Herdman M, Pavesi M, et al. Using EQ-5D-3L and OAB-5D to assess changes in the health-related quality of life of men with lower urinary tract symptoms associated with benign prostatic hyperplasia. Qual Life Res 2017 May; 26(5): 1187-1195. doi: 10.1007/s11136-016-1460-x. Epub 2016 Nov 28. https://doi.org/ $10.1007 / s 11136-016-1460-x$ 